\title{
Inledning: flerspråkighet
}

\section{Av MEMET AKTÜRK-DRAKE, ELLEN BIJVOET, NATALIA GANUZA \& ANNA SAHLÉE}

I det här temanumret av Språk och stil presenteras aktuell forskning om flerspråkighet genomförd av en rad forskare som är verksamma inom området i Sverige. Författarna till de olika bidragen har bjudits in av oss redaktörer för att säkerställa att temanumret täcker såväl centrala aspekter av forskningsfältet, som nyare utvecklingar. Flerspråkighet är långt ifrån ett nytt fenomen, men dess folkliga utbredning, synlighet och relevans har med tiden stärkts inte minst till följd av ökad globalisering, mobilitet och nya teknologier (Cenoz 2013). Även i forskningen märks ett ökat intresse för flerspråkighet. Det inrättas nya centra och institutioner, skapas nya utbildningar och kurser, anordnas konferenser och skrivs många böcker och artiklar med inriktning mot flerspråkighet (se även Salö, Hyltenstam, Stroud \& Karlander i det här numret).

Den allmänna synen på flerspråkighet har genomgått en radikal förändring de senaste 50 åren. Medan flerspråkighet i Sverige fram till 1970-talet uppfattades som relativt ovanligt och marginellt i samhället (Bajqinca 2019), utgör den idag en väsentlig del av många människors vardag. År 1950 uppskattades endast cirka var tjugofemte person i Sverige ha ett annat modersmål än svenska, idag rör det sig om var femte person. Uppskattningsvis talas det upp emot 200 olika språk i Sverige. Samtidigt har engelskan fått en allt starkare roll i samhället. Engelskan betraktas numera av många forskare som ett de facto andraspråk (Phillipson 1992 s. 25, Hyltenstam 2004 s. 52). Undersökningar visar att närmare nio av tio svenskar behärskar engelska så pass bra att de kan använda det i vardagliga samtal, vilket utgör en av de högsta siffrorna i länder där engelska inte är ett majoritetsspråk eller ett officiellt språk (TNS Opinion \& Social 2012, se även EFEPI 2019). Sverige är således, liksom de flesta andra länder idag, ett synnerligen flerspråkigt samhälle.

Trots att synen på flerspråkighet har blivit positivare över tid lever många felaktiga och negativa föreställningar fortfarande kvar om flerspråkighet (Bajqinca 2019, TNS Opinion \& Social 2012). Detta synliggörs till exempel i allmänna och mediala debatter som rör språk och utbildning. På många sätt kan man hävda att det svenska samhället fortfarande genomsyras av en tydlig enspråkighetsnorm. Än idag konfronteras flerspråkiga individer med för- 
domar, negativa attityder och diskriminering som har språkliga grunder (t.ex. Boyd \& Bredänge 2013, TNS Opinion \& Social 2015, Bijvoet 2020). I det avseendet har därför dagens flerspråkighetsforskare även ett ansvar att sprida aktuell kunskap om flerspråkighet till relevanta samhällsaktörer.

Som bidragen i det här temanumret vittnar om är flerspråkighetsforskning ett mångfacetterat och tvärvetenskapligt område. Det bedrivs forskning utifrån en rad olika teoretiska och metodologiska utgångspunkter. Förenklat kan forskningen indelas i tre övergripande perspektiv: sociolingvistiska, psykolingvistiska och utbildningsrelaterade (jfr Flerspråkighet - en forskningsöversikt 2012, se även The Handbook of Bilingualism and Multilingualism 2012, Salö m.fl. i detta temanummer). Självklart finns ingen skarp gräns mellan dem. Den sociolingvistiska forskningen omfattar bland annat frågor om flerspråkighet på samhällsnivå: exempelvis om och hur en nations språk- och utbildningspolitik upprätthåller och stödjer flerspråkighet, vilka dominerande ideologier om språk som finns och när, hur och var dessa tar sig uttryck. Den sociolingvistiska forskningen innefattar också studier av de levnadsvillkor som råder för olika språkliga minoriteter och vilka möjligheter och resurser som finns tillgängliga för dem att lära sig, bibehålla och utveckla sina olika språk (se bl.a. Lainio \& Pesonen i detta temanummer). Dessutom ingår forskning om flerspråkiga praktiker, kopplingen mellan språk och identitet och attityder till olika språkbruk (se bl.a. Bijvoet \& Senter i detta temanummer).

Den psykolingvistiska forskningen om flerspråkighet studerar till exempel vad som kännetecknar andraspråksinlärning och flerspråkig utveckling i relation till förstaspråksinlärning och enspråkig utveckling och vilka interna och externa faktorer som påverkar språkinlärningen (se bl.a. Abrahamsson \& Bylund samt Bohnacker m.fl. i detta temanummer). Den rör också likheter och skillnader mellan flerspråkig och enspråkig lagring, processning, förståelse och produktion och hur flerspråkigheten påverkar hjärnans olika funktioner (se bl.a. Bylund i detta temanummer). Dessutom omfattar den studier av vad som sker med språkliga färdigheter när en person slutar att använda ett tidigare inlärt språk, eller använder det på ett annorlunda sätt än tidigare.

Utbildningsrelaterad forskning om flerspråkighet omfattar till exempel hur utbildning i olika språk kan och bör organiseras i olika samhälleliga kontexter och i vilken form och omfattning som olika utbildningsmodeller lämpar sig bäst för att stödja flerspråkig utveckling (se t.ex. García 2009). Den innefattar perspektiv på undervisningens roll och effekter, klassrumsnära studier av hur undervisningen i olika språk och skolämnen kan utformas för att stötta flerspråkiga elevers parallella språk- och kunskapsutveckling. Den utbildnings- 
relaterade flerspråkighetsforskningen studerar också hur utbildningens organisation, form och genomförande kan bidra till att lyfta fram vissa språk och talare, och osynliggöra andra, och därigenom tillskriver dem olika värde.

I det här temanumret har de utbildningsrelaterade perspektiven fått en något undanskymd roll. Det motiveras med att den utbildningsrelaterade forskningen om flerspråkighet har varit framgångsrik i att synas även utanför det egna forskningsområdet. Här har vi framför allt valt att fokusera på frågor och aspekter som inte är lika välkända utanför det egna området.

\section{Bidragen i det här temanumret}

Bidragen i det här temanumret gör nedslag i några olika områden av den numera väletablerade och dynamiska flerspråkighetsforskningen. Förhoppningen är att urvalet kan läsas och vara relevant både för språkforskare och för studenter och andra med intresse för frågor om flerspråkighet. Bidragen är skrivna av forskare som i de flesta fallen har sin institutionella hemvist $\mathrm{i}$ Sverige, men texterna rör språkliga förhållanden i flera samhälleliga kontexter. Bidragen utgår från en rad olika teoretiska perspektiv, material och metoder och texterna åskådliggör på så sätt flerspråkighetsforskningens bredd och tvärvetenskapliga natur. Även formmässigt skiljer sig bidragen åt - medan några erbjuder en internationell och nationell översikt över ett avgränsat forskningsområde presenterar andra resultaten från en eller några få enskilda undersökningar. Tillsammans behandlar de sju bidragen som ingår i temanumret flerspråkighetsforskningens historik i Sverige, finskans förändrade roll och status i Sverige under 2000-talet, flerspråkig utveckling hos barn, avancerad andraspråksinlärning hos vuxna, relationen mellan flerspråkighet och tanke, språkliga praktiker och språkattityder med koppling till ungdomar i förorten samt relationen mellan sexualitet och språk i nutida migrationskontexter.

Den inledande artikeln av Salö, Hyltenstam, Stroud och Karlander består av ett redigerat ämneshistoriskt samtal mellan två seniora och två mer juniora flerspråkighetsforskare. Tillsammans diskuterar de etableringen och utvecklingen av två-/flerspråkighetsforskningen i svensk kontext. De redogör för områdets övergripande utvecklingslinjer, teman, frågeställningar och aktörer. Samtalet börjar i en begreppsdiskussion om relationen mellan benämningen två- respektive flerspråkighet och hur ett skifte i användningen av dessa speglar en pågående förändring inom fältet, både nationellt och internationellt. De 
fyra samtalsdeltagarna har alla haft sin hemvist vid Centrum för tvåspråkighetsforskning, Stockholms universitet. Under samtalet belyses och diskuteras Centrets framflyttade position inom flerspråkighetsforskningen i Sverige och den viktiga roll som dess formella institutionsbildning har haft för att främja områdets utveckling och bredd. Samtidigt pekar de på att flerspråkighetsforskningen successivt fått en bredare institutionell förankring vid olika universitet och inom olika ämnen. Bidraget erbjuder en övergripande historisering av flerspråkighetsforskningen i Sverige och belyser de aspekter av ämnet som har kommit att bli mest centrala över tid.

I temanumrets andra bidrag diskuterar Lainio och Pesonen finskans ställning i Sverige och hur olika faktorer har påverkat och skapat förutsättningar för finskans överlevnad under 2000-talet. Tidsperioden är viktig att belysa eftersom flera viktiga språkpolitiska steg har tagits för att stärka och stödja de nationella minoritetsspråken, däribland finskan. I artikeln tillämpar författarna ett nytt teoretiskt ramverk som utgår från tre olika dimensioner (språkkompetens, möjlighet att använda språket samt vilja att använda det) som var och en studeras på mikro-, meso- och makronivå. Materialet utgörs av såväl tidigare publicerade undersökningar och rapporter som nya intervjuer från en uppföljningsstudie. Övergripande argumenterar författarna för att finskan befinner sig i en nedåtgående spiral. Finskans långvariga utsatthet för språkliga assimileringsstrategier, allmänhetens historiskt sett negativa attityder gentemot finskan (och minoritetsspråkens användning i stort), kommunernas låga prioritering, modersmålsundervisningens begränsade omfattning samt ett bristande språkpolitiskt engagemang hos individer med finskt ursprung har haft långtgående negativa konsekvenser för finskans bevarande i Sverige. Den språkpolitiska satsningen som gjorts på makronivå under 2000-talet framställs i det ljuset som too little, too late. För att kunna vända den negativa trenden krävs enligt artikelförfattarna kraftfullare åtgärder (däribland införandet av tvåspråkig utbildning och mer omfattade modersmålsundervisning) och en större språkpolitisk medvetenhet och engagemang bland sverigefinnar.

Bidraget av Bohnacker, Haddad, Lindgren, Öberg och Öztekin rör flerspråkig utveckling hos barn. I artikeln presenteras resultaten från den hittills största svenska tvärsnittsstudien av tvåspråkiga barns ordförrådsutveckling. I undersökningen deltog sammanlagt 202 barn i åldrarna 4-7 år, vars receptiva och produktiva ordförråd mättes med jämförbara test på barnens två språk (svenska och turkiska respektive svenska och arabiska). Därefter har resultaten analyserats i relation till flera viktiga bakgrundsfaktorer som man vet kan påverka språkutvecklingen, såsom ålder, socioekonomisk status (föräldrarnas 
utbildningsbakgrund), språklig exponeringsgrad och deltagande i modersmålsundervisning. Resultaten faller delvis ut som förväntat - man finner en tydlig ålderseffekt på barnens receptiva och produktiva ordförråd på båda språken, som får tydligast utslag på majoritetsspråket svenska. För minoritetsspråket visar resultaten att exponeringsgraden för språket i hemmet spelar en viktig roll för barnens ordförrådsutveckling. Några av resultaten överraskar, till exempel att man inte finner någon statistiskt signifikant korrelation mellan barnens ordförråd och familjernas socioekonomiska status, vilket man sett i många tidigare studier. I en grundlig diskussion fördjupar och problematiserar författarna resultaten och ger flera uppslag till vidare forskning.

I Abrahamssons och Bylunds artikel diskuteras två skilda hypoteser som använts för att förklara slutlig behärskningsnivå vid andraspråksinlärning. Enligt den så kallade åldershypotesen beror skillnader i slutlig behärskningsnivå främst på när talaren påbörjade inlärningen av andraspråket, det vill säga den är ett resultat av talarens startålder. Endast inlärning från födseln eller från tidig ålder antas enligt hypotesen leda till infödd eller inföddlik språkbehärskning. Den så kallade tvåspråkighetshypotesen utgår i stället ifrån att enspråkiga och tvåspråkiga talares språkbehärskning alltid skiljer sig åt, eftersom det ligger i tvåspråkighetens natur och är en effekt av den. I artikeln testar Abrahamsson och Bylund antagandet att tvåspråkiga talares behärskning av andraspråket nödvändigtvis måste skilja sig från enspråkiga talares. Med en unik forskningsdesign har de jämfört fyra olika grupper med enspråkiga och tvåspråkiga talare som påbörjat inlärningen av svenska i olika åldrar. Deltagarna fick utföra ett omfattande testbatteri som inkluderade många olika språkliga dimensioner. Resultaten visade med stor tydlighet att skillnader i inföddlik behärskning inte påverkades avsevärt av om inlärningen skett enspråkigt eller tvåspråkigt. Resultaten förklarades bättre utifrån skillnader i deltagarnas startålder för inlärningen av svenska. Deltagare som lärt sig svenska från födseln (d.v.s. både enspråkiga och simultant tvåspråkiga) liknade varandra i sin inföddlika behärskning medan de med senare inlärningsstart (d.v.s. sekventiellt tvåspråkiga invandrarbarn och sekventiellt enspråkiga adoptivbarn) i sin tur liknade varandra i det avseendet att behärskningen inte var fullständigt inföddlik. Abrahamsson och Bylund drar således slutsatsen att det rör sig om ålderseffekter snarare än tvåspråkighetseffekter.

Att det är en grannlaga och komplex uppgift att forska om och försöka förstå hur människan lagrar och processar flera språk framgår tydligt i Bylunds artikel om flerspråkighet och tanke. I artikeln lotsar Bylund läsaren genom den forskning som rör »språklig relativism», det vill säga hur språk påverkar 
tänkandet. Bylund ger en bild av hur detta psykolingvistiska forskningsfält har vuxit fram och på senare år berikats av studier som tar fasta på flerspråkiga individers tolkning av information - och vilka språkligt relaterade faktorer som kan förklara vilken tolkning som görs. Bland annat redogörs för studier av hur individer uppfattar skeenden som rör tid och rörelse i relation till hur de språk som individen behärskar kodar denna information. Dessutom tydliggörs hur faktorer som startålder, språkbehärskning och grad av språkanvändning också i detta avseende har betydelse (jfr Abrahamsson \& Bylunds bidrag). I texten ges rikligt med exempel för att illustrera de olika studierna som refereras, varav flera inbegriper svenska. Bylund resonerar om vilken riktning framtida forskning kan ta och ger flera uppslag till framtida studier om flerspråkighet och tanke.

I Bijvoets och Senters bidrag till temanumret står språkliga resurser hos ungdomar med bakgrund i språkligt heterogena bostadsområden (förorter) $\mathrm{i}$ fokus. Artikeln behandlar förortsförankrat talspråk i svensk kontext. Bijvoet och Senter beskriver de enregistreringsprocesser som förortsförankrat tal har genomgått, vilka har lett till att talet är igenkännligt för språkbrukare både i och utanför mångspråkiga förortsområden. Med utgångspunkt i empiriska data från flera olika studier illustreras attityder till och föreställningar om förortsindexerad svenska ur såväl ett inifrån- som ett utifrånperspektiv - och mot bakgrund av i samhället dominerande språkideologiska föreställningar. Författarna lyfter särskilt fram den variation som finns inom förortsindexerat tal - från slangpräglade ungdomsstilar till en mer formell, standardnära svenska utan slangord men med en kvardröjande »förortsk klang» - och diskuterar frågan om benämningar för de aktuella talspråkspraktikerna: Hur benämns de, och bör de överhuvudtaget benämnas? Bijvoet och Senter beskriver spänningsfältet mellan å ena sidan den inom språkforskningen allt mer dominerande synen på varieteter som sociala konstruktioner, och å andra sidan behovet av att ibland (avgränsa och) förenkla beskrivningen av komplexa språkliga miljöer för att synliggöra olika former av språklig variation. Artikeln utgör således ett bidrag till den inom sociolingvistiken pågående diskussionen om språksyn och named languages.

Temanumrets avslutande bidrag representerar ett av flerspråkighetsforskningens mer nytillkomna inriktningar. Milani, Mortensen och Levon skriver att frågor om sexualitet hittills haft en alltför undanskymd plats inom flerspråkighetsforskningen, i synnerhet i nordisk kontext. Deras ambition är därför att visa hur aktuell forskning om flerspråkighet och migration kan och bör inkorporera ett tydligare queer-perspektiv och vilka implikationer det $\mathrm{i}$ 
så fall får. Artikeln utgår från två skilda exempel och kontexter: Danmark och Israel. Genom kritisk diskursanalys av en eklektisk mix av skriftliga och muntliga texter synliggör artikelförfattarna hur idéer om språk och identitet ofta kopplas samman med bestämda föreställningar om sexualitet och sexuella normer. I artikeln diskuteras till exempel hur migranter i Danmark måste genomgå utbildning $\mathrm{i} \gg$ dansk seksualmoral» och anamma vissa sexuella normer för att »passa in» och bli positionerade som »goda invandrare». I Israel finns en liberal lagstiftning som erkänner sexuella minoriteters rättigheter, men artikelförfattarna visar att den sexuella frigörelsen inte är lika tillgänglig för alla och inte oberoende av varifrån någon kommer eller vilka språk den talar.

\section{Litteratur}

Bajqinca, Nuhi, 2019: Mother tongue education - The interest of a nation. A policy study in Sweden 1957-2017. Göteborg: Institutionen för sociologi och arbetsvetenskap, Göteborgs universitet.

Bijvoet, Ellen, 2020: Attityder till spår av andra språk i svenskan - en forskningsöversikt. (Rapporter från Språkrådet 15.) Stockholm: Institutet för språk och folkminnen/Språkrådet.

Boyd, Sally \& Bredänge, Gunlög, 2013: Attityder till brytning - exemplet utländska lärare i svenska skolor. I: Svenska som andraspråk - i forskning, undervisning och samhälle, red. av Kenneth Hyltenstam \& Inger Lindberg. (2:a uppl.) Lund: Studentlitteratur. S. 437-457.

Cenoz, Jasone, 2013: Defining Multilingualism. I: Annual Review of Applied Linguistics 33. S. 3-18.

EFEPI = Education First English Proficiency Index, 2019: www.ef.com/epi, hämtad 2020-09-15.

Flerspråkighet - en forskningsöversikt, red. av Kenneth Hyltenstam, Monica Axelsson \& Inger Lindberg. (Vetenskapsrådets rapportserie 5:2012) Stockholm: Vetenskapsrådet 2012.

García, Ofelia, 2009: Bilingual Education in the 21 st Century: A Global Perspective. Oxford: Wiley-Blackwell.

Hyltenstam, Kenneth, 2004: Engelskan, skolans språkundervisning och svensk språkpolitik. I: Engelskan i Sverige: Språkval i utbildning, arbete och kulturliv. (Småskrift utgiven av Svenska språknämnden.) Stockholm: Norstedts. S. 36-110.

Phillipson, Robert, 1992: Linguistic Imperialism. Oxford: Oxford University Press.

The Handbook of Bilingualism and Multilingualism, red av Tej K. Bahtia \& William C. Ritchie. (2 ${ }^{\text {nd }}$ Edition) Oxford: Wiley-Blackwell 2012. 
12 Memet Aktürk-Drake, Ellen Bijvoet, Natalia Ganuza \& Anna Sahlée

TNS Opinion \& Social 2012: Special Eurobarometer 386 - Wave EB77.1: Europeans and their languages. Brussels: at the request of Directorate-General Education and Culture, Directorate-General for Translation and Directorate-General for Interpretation.

TNS Opinion \& Social 2015: Special Eurobarometer 437 - Wave EB83.4: Discrimination in the EU in 2015. Brussels: at the request of the Directorate-General for Justice and Consumers. 